\title{
ZONING FOR AESTHETIC OBJECTIVES: A REAPPRAISAL
}

\author{
J. J. DUREMinier, JR.*
}

Zoning for aesthetic objectives is a perplexing problem. According to traditional doctrine the community may not use the police power to accomplish primarily aesthetic objectives, but planners and lawyers have long had serious doubts whether in fact this doctrine describes what courts have done in the past in approving ordinances, whether it may be used to predict what they will do in the future, and whether it states a desirable norm for decision. The problem has been rather fully explored elsewhere along lines of traditional legal analysis, ${ }^{1}$ and in view of the previous studies perhaps a more fruitful contribution can be made here by looking at the problem and the doctrine from a different perspective.

The primary object of this article will be to examine contemporary doctrine as an instrument of community policy and to focus attention upon its adequacy as an implement of the sound judicial skepticism from which it emanates. As will appear, the dearth of good empirical studies in the field of aesthetics seriously impedes the full consideration of many facets of the problem of zoning for aesthetic objectives, and the ideas and conclusions expressed herein are not comprehensively developed. Many of the ideas and conclusions also are tentative and subject to exception, although expressed without qualification. It is hoped, however, that this article will stimulate more thinking about the types of aesthetic control rational land planning requires, which is the basic issue.

\section{The Existing Confusion}

The usual statement of doctrine is that the police power cannot be used to accomplish purely aesthetic ${ }^{2}$ objectives, but that aesthetic objectives may be taken

* A.B. 1948, Harvard University, LL.B. I95I, Yale Law School. Associated with Davidson, Dawson, and Clark, New York, I951-1953. Member of the New York bar. Assistant Professor of Law, University of Minnesota.

${ }^{1}$ A comprehensive technical analysis with a good collection of cases may be found in Rodda, The Accomplishment of Aesthetic Purposes Under the Police Power, 27 So. Calif. L. Rev. I49 (1954). Sce also Donnelly, The Police Power and Esthetic Zoning, 5 J. B. A. KAN. 215 (1937); Gardner, The Massachusetts Billboard Decision, 49 Harv. L. Rev. 869 (1936); Light, Aesthetics in Zoning, 14 MrNN. L. REv. 109 (1930); Baker, Aesthetic Zoning Regulations, 25 MrcF. L. Rev. 124 (1926); Larremore, Public Aesthetics, 20 HARv. L. REv. 35 (1906). For a different doctrinal approach see Noel, Unaesthetic Sights as Nuisances, 25 CaN. L. Q. 17 (I939).

2 The word "aesthetic" is many hued. It was first applied in Germany by Baumgarten in 1750 to 2ppreciation and criticism of the beautiful. Next, Kant applied it to the "science" or "metaphysics" of sensuous perception. According to I Oxrord ENGLISH Dicrionary I47 (1933), ". . . Baumgarten's usc of aesthetik found popular acceptance, and appeared in England after 1830, though its adoption was long opposed. Recent extravagances in the adoption of a sentimental archaism as the ideal of beauty have still further removed aesthetic and its derivatives from their etymological and purely philosophical meaning." Although the Dictionary goes on to say Kant's meaning is now obsolete, F. S. C. Northrop 
into consideration where for reasons of public health, safety or morals ${ }^{3}$ the zoning regulation may be sustained as a proper exercise of the police power. In order to view this formulation in perspective it is necessary to make a short detour here into history.

Early in this century, community officials, responding to outraged popular sensibilities, began to take action against billboards and advertising posters which had in the eighteen nineties suddenly mushroomed on most every vacant lot. Ordinances and statutes were passed regulating, and in some instances entirely prohibiting, billboards. Most of these regulations were quickly killed by the courts which held that such regulations, having been enacted for aesthetic objectives alone, were without the scope of the police power. ${ }^{4}$ Yet with the ever-widening desecration of the landscape and with the public outcry against billboards, it seems inevitable that the courts would not long restrain the community officials. And the courts did not.

The Missouri Supreme Court in IgII in St. Louis Gunning Advertising Co. v. St. Louis" provided the doctrinal shift by taking the postulate that the police power might be exercised to protect community health, safety, and morals and then finding, as facts, that billboards ${ }^{6}$

... endanger the public health, promote immorality, constitute hiding places and retreats for criminals and all classes of miscreants. They are also inartistic and unsightly. In cases of fire they often cause their spread and constitute barriers against their extinction; and in cases of high wind, their temporary character, frail structure and broad surface, render them liable to be blown down and to fall upon and injure those who may happen to be in their vicinity. The evidence shows and common observation teaches us that the ground in the rear thereof is being constantly used as privies and dumping ground

has recently resurrected and applied the word a la Kant; see The MEEtrNg of EAst and West c. I2 (I946).

The Oxford English Dictionary gives two current uses of the word (p. 148):

"......

2. Of or pertaining to the appreciation or criticism of the beautiful.

3. Of persons, animals: Having or showing an appreciation of the beautiful or pleasing; tasteful, of refined taste. Of things: In accordance with the principles of good taste (or what is conventionally regarded as such)."

To these uses I append a qualification. In this article the only phenomena to which the word will be applied will be phenomena evident to sight only, not discernible by the other senses. To avoid confusion, however, I might point out that the word is essentially multiordinal and its meaning will vary herein with the context in which it is used.

${ }^{3}$ Sometimes welfare is added to health, safety or morals. Welfare would seem to give the courts a ready-made word to use when and if they openly recognize the aesthetic factor.

Caveat: some courts do not use the doctrine herein discussed. See infra notes 19, 55, 70.

Ordinances held invalid in Crawford v. Topeka, 51 Kan. 756, 33 Pac. 476 (I893); People v. Green, 85 App. Div. 400, 83 N.Y.S. 460 (Ist Dep't 1903); Bill Posting Sign Co. v. Atlantic City, 7 I N.J.L. 72, 58 Atl. 342 (1904); Bryan v. Chester, 212 Pa. 259, 6r Atl. 894 (1905); Chicago v. Gunning System, 214 Ill. 628, 73 N.E. 1035 (1905); Passaic v. Paterson Bill Posting Co., 72 N.J.L. 285, 62 Atl. 267 (1905); State v. Whitlock, 149 N.C. 542,63 S.E. 123 (I908); Varney \& Green v. Williams, 155 Cal. 318, roo Pac. 867 (r909); People ex rel. Wineburgh v. Murphy, I95 N.Y. I26, 88 N.E. I7 (rg09); Curran Co. v. Denver, 47 Colo. 22I, 107 Pac. 26I (I9ro); Haller Sign Works v. Physical Culture Training School, 249 Ill. 436, 94 N.E. 920 (rgrr).

235 Mo. 99, 137 S.W. 929 (I91x), appeal dismissed, 231 U.S. 761 (I913).

- 235 Mo. at I 45, I 37 S.W. at 942 . 
for all kinds of waste and deleterious matters, and thereby creating public nuisances and jeopardizing public health; the evidence also shows that behind these obstructions the lowest form of prostitution and other acts of immorality are frequently carried on, almost under public gaze; they offer shelter and concealment for the criminal while lying in wait for his victim; and last, but not least, they obstruct the light, sunshine, and air, which are so conducive to health and comfort.

The earlier cases had regarded aesthetic objectives as the predominating motive of billboard regulation and condemned the regulations for that reason; St. Louis Gunning initiated the deliquescence of earlier doctrine by regarding as primary the 'motives of safety, health, and morality and by sustaining the regulation for that reason.

From St. Louis Gunning and later cases following it emerged the postulates of contemporary doctrine:

(a) the police power may not be used to attain objectives primarily aesthetic; but

(b) the police power may be used to attain objectives primarily related to health, safety or morals;

based upon the following proposition of fact:

(a) billboards and signs are primarily deleterious to health, safety or morals. Strictly speaking, this proposition is an unproven hypothesis, and there is strong reason to suspect that it is contrary to fact in most contexts. It is important to determine if the underlying proposition of fact is true, for if it is not true and if in deed (if not in word) the courts sustain regulation of billboards, then it will have to be admitted that the doctrine is an inadequate description of the factors that move decision in this context of fact.

It seems plain that the primary offense of billboards is ugliness. Any jerry-built billboard may of course be a menace to safety and a fire hazard, but the billboard regulations are not limited to keeping the signboard screws tight. Limitations are placed upon size, positions, and frequency of placement. In some areas billboards have been entirely prohibited, ${ }^{7}$ although the unsafe aspects might be easily obviated by proper construction requirements.

${ }^{7}$ Colo. Stat. Ann. c. $48, \$_{403}(4)-(7)$ (1953 Supp.). Prohibited within 500 fect of scenic parkway or within 250 feet of any historic monument, shrine, or similar object, or if obstructing any "scenic view" designated as such by the Secretary of State. Secretary may order removal of sign "unsightly by reason of lack of maintenance and repair."

Conn. Gen. Stat. Rev. $\$ 4688$ et seq. (1949). Prohibited within roo feet of any public park, playground, cemetery or state forest, or within 15 feet of any highway.

Del. Code ANN. \$rIo3 et seq. (1953). Prohibited within 25 feet of park, playground, school, church or highway.

Fla. Stat. Ans. c. 479.II(x) (1952). Prohibited within roo feet of any public park, playground, school, church or cemetery.

IDAfo CODE $\$$ I8-70I7 (1947). Prohibited to paint or place advertising sign on any rock or similar natural object.

ME. REv. Stat. c. 20, \$II6 (I944). Prohibited within 300 feet of any public park, playground, school, church, cemetery or reservation, or within 50 feet of any highway.

Mrnn. Stat. ANv. $\$ 16.57$ (1945). Prohibited within $1 / 8$ mile of capitol.

Nev. CoMp. LAws $\$ 264$ (Hillyer, 1929). Prohibited if signs "destroy the natural beauty of the secnery." 
In business districts billboards and advertising signs have been prohibited unless the signs refer to business conducted or products sold on the premises. This provides a good illustration of the true objectives of community officials in acting against billboards and of the contrary-to-fact proposition of fact necessary under traditional doctrine to sustain this action. In the recent case of Murphy, Inc. v. Westport, the plaintiff billboard company asked for an injunction restraining the enforcement of the provision in Westport's zoning ordinance which prohibited "Billboards or advertising signboards . . . in all business districts except as they refer to business conducted on the property on which the billboards stand." The object of the exception in this sweeping prohibition is to make community action more palatable to local shopkeepers who wish to advertise their wares (and who are also sometime voters). The provision strikes primarily at billboard companies which erect billboards on vacant lots. For a city wishing to rid itself of all billboards, it is an expedient compromise. The Superior Court granted an injunction on the ground that this classification was unreasonable and "illegally discriminative"; it found the regulations contained "no provisions as to size, construction or site designed to insure the safety of the public; ... the advertising matter appearing on the sign determines its safety to the public. Of course this is nonsense."' It likewise dismissed the contention that the classification was reasonably related to public health or morals. The Connecticut Supreme Court of Errors reversed. It stated:10

In the earlier cases, courts apparently did not realize as clearly as they do now, as the result of facts found upon various trials, that billboards may be a source of danger to travelers upon highways through insecure construction, that accumulations of debris

N. Y. Conservation Law $\$ 675$ (McKinney, x95I). Prohibited within 500 feet of parks and parkways. N. Y. Public Authonities Law $\S 569-b$. Prohibited within 500 feet of the Bronx-Whitestone bridge and the Brooklyn-Battery bridge [tunnel?].

N. C. Gen. StAT. $\$ 105-86$ (I949). Prohibited within 200 feet of entrance to school, church, or public institution.

PA. Statr. Ans. tit. 36, $\$ 655.2$ (Purdon, 1942). Prohibited within 500 feet of Rim Parkway.

S. D. Cone $\$ 28.0905$ (1939). Prohibited within 300 feet of any cemetery.

VT. STAт. $\$ 7689$ (1947). Prohibited within 300 feet of any park, playground or cemetery. teries.

VA. CoDE $\$ 33-317$ (1950). Prohibited within 500 feet of parks, parkways, playgrounds, and ceme-

West VA. CODE ANn. §I72I(57) (x949). Prohibited within 500 feet of any park, playground, school, church, or cemetery.

${ }^{8}$ I3I Conn. 292, 40 A.2d r77 (r944).

'Murphy, Inc. v. Westport, Record, Vol. A-zor, p. II. In surveying the history of billboard regulation, the Superior Court was refreshingly candid (at pp. I6, II): "The earlier attitude appears to have been that billboard regulation was simon-pure aesthetic regulation and as such was condemned. Adverse public opinion against unsightly signs along highways quite probably had much to do in the rapid change of legal thought. This public opinion was not concerned with thoughts of safety, morals or welfare. It was occasioned by the disfigurement of the landscape and by the marring of the beauty of Nature. Yet the courts, somewhat sophistically, it seems to me, with many protestations against the use of aesthetic standards, urged with rather fantastic reasoning that what previously had no relationship to public safety had now developed into a public menace which an enlightened community not only had a right to regulate but, indeed, would be almost wayward in failing to control. . . . Billboard regulation is within the police power, regardless of whether one relies on the reasons to which the courts still cling or on those which are treated like step-children, but which, at least to my satisfaction, furnish the hidden impelling motive for modern legal thought."

${ }^{10}$ I3 I Conn. 295, 297, 303, 40 A.2d I78, I79, 182. 
behind and around them may increase fire hazards and produce unsanitary conditions, that they may obstruct the view of operators of automobiles on the highway and may distract their attention from their driving, that behind them nuisances and immoral acts are often committed, and that they may serve as places of concealment for the criminal. ...

As far as the record shows, the trial court did not have before it any adequate basis of facts upon which to determine that the invalidity of the provisions of the ordinance in question had been established. If we were to sustain its decision, we would in effect be holding that, as a matter of law, the legislative body cannot, with such exceptions as are provided in the ordinance before us, constitutionally prohibit billboards in the business zones of any of our towns, no matter what may be the circumstances or justification which existed in the particular case. We cannot so hold.

As the trial court did not have before it sufficient facts to enable it to determine whether or not the plaintiffs were entitled to relief, we must remand the case for further proceedings. (italics supplied.)

What kind of facts did the court want the trial court to consider? Facts tending to prove that the prohibition of all signs except those advertising goods sold on the premises promoted public safety and lessened traffic hazards? The Superior Court considered and rejected such evidence. Facts showing that the prohibited billboards created a danger to public health? Facts showing that billboards in open fields increased the danger of fire more than signs attached to buildings? Facts showing that nasty things go on behind billboards and that they afford hiding places for criminals and cops? Except in rare, isolated cases such facts are simply unattainable. For instance, a special master in the next-door state of Massachusetts, where the factual contexts should be fairly similar, after hearing evidence for II4 days found: ${ }^{11}$

In some isolated cases, certain signs and billboards in this Commonwealth have been used as screens to commit nuisances, hide law breakers, and facilitate immoral practices. Around some few filth has been allowed to collect, and some have shut out light and air from dwelling places. In and around others, rubbish and combustible materials have been allowed to collect, which to some degree tends to create a fire hazard. Those instances were all so rare, compared with the total number of signs and billboards in existence, that I am unable to find upon the evidence that signs and billboards, in general, as erected and maintained in this Commonwealth, have screened nuisances, or created a danger to public health or morals, or facilitated immoral practices, or afforded a shelter for criminals, or created or increased the danger of fire, or hindered firemen in their work.

One of the more recent examples of community action against offensive advertising signs is the prohibition of signs overhanging the sidewalks in fashionable shopping areas. Although New York has long prohibited overhanging signs on Fifth Avenue, Park Avenue, and other East Side and downtown streets, ${ }^{12}$ only re-

\footnotetext{
${ }^{11}$ General Outdoor Advertising Co. v. Dep't of Public Works, 289 Mass. 149, 170, 193 N.E. 799, 809 (1935), appeal dismissed, 297 U.S. 725 (1936).

${ }^{12}$ N. Y. City Administrative Code c. $26, \$ \mathrm{~B}_{2} 6-7,0$. The attractiveness of Fifth Avenue to a large extent may be credited to the Fifth Avenue Association, founded in 1907, which is a voluntary organization of merchants in the Fifth Avenue area that works closely with city officials in controlling the
} 
cently have other cities become interested in achieving the Fifth Avenue "uncluttered look" on certain of their main business arteries. In two recent cases the ordinances of Detroit and Minneapolis prohibiting overhanging signs on fashionable Woodward and Nicollet Avenues respectively were upheld.13 The city officials were pretty clearly not much concerned about safety, for if signs hanging from the best stores in town are really unsafe, reason demands that shabby ones hanging from stores in a low-price district also be prohibited. The practical result is that people who shop the best stores have aesthetic preferences which may be recognized and protected by community officials.

While it is difficult to determine what is the primary offense of much land use, the simulation of blindness affords a simple rule-of-thumb: if a use is offensive to persons with sight but not offensive to a blind man in a similar position, the use is primarily offensive aesthetically. Applying this rule to the regulation of outdoor advertising, it seems clear that except in certain areas where signs provide dangerous distraction to traffic their offense is primarily their unsightliness. Is a well-constructed billboard or overhanging sign inimical to a blind man's safety, health or morals? Does it offend him in any way? The function of advertising signs is visual solicitation, and their offensiveness would seem to lie in the fact that their assault on the eyes in some contexts is most unpleasant.

Where courts have allowed community officials to prohibit what are in reality aesthetically objectionable land uses, their language indicates that they have closed their eyes to the real underlying facts. Yet what courts say and what courts do are two different things, and it is not proper to conclude from their language that courts do not know what is going on. Except in so far as the doctrine ensnares the unwary planner or judge who puts excessive faith in the plain meaning of words, it does not prevent any court from holding that community officials may zone for aesthetic objectives. But it seems to me that the doctrine may properly be criticized as meaningless theory, i.e., it does not describe past court response nor enable one to predict future court response. More will be said of this later. More important, and partly resulting from its aforementioned inefficacy, it appears to be an inadequate formulation of community objectives and an unnecessary hindrance to devising the most efficient means of achieving these objectives.

\section{Clarification of Community Objectives}

What are the community objectives here? They must be clarified if the inadequacy of contemporary doctrine is to become evident and courts are to function as they should. It is difficult to know how far back toward basic value premises

design of buildings and advertising signs. To encourage high standards of design the Association makes biennial architectural awards for the best façades on new and altered buildings. See Coffin, beauty or bust, Promenade, May, I950.

${ }^{13}$ 1426 Woodward Avenue, Inc. v. Wolff, 312 Mich. 352, 20 N.W.2d 217 (I945); Oscar P. Gustafson v. Minneapolis, $23 \mathrm{I}$ Minn. 27I, 42 N.W.2d 809 (1950). Cf. Preferred Tires v. Hempstead, I73 Misc. Io17, I9 N.Y.S.2d 374 (Sup. Ct. 1940); Mallory v. New Rochelle, 184 Misc. 66, 53 N.Y.S.2d 643 (Sup. C. 1944), affirmed without opinion, 295 N.Y. 712 (1946). 
one must go in order to achieve the needed clarity. It is best perhaps to begin with some of what appear to me to be the merest truisms pertinent to the problem. These will sound very dogmatic, but I hope to elucidate and justify them in what will follow.

Among the strongest preferences of our society is for land use to be determined largely by private volition, and legal doctrine which implements this preference is a social hypothesis that goal values can more readily be achieved with a minimum of community intervention. ${ }^{14}$ The St. Louis Gunning doctrine is such an hypothesis. Individuals using their land as they desire are expected to increase total community wealth, encourage self-respect, and foster healthier and more beautiful surroundings. Thus we prefer that community officials should not intervene in the allocation and planning of land use unless the privately determined use of land deprives other persons within the community of basic values, among which is the enjoyment of beauty by a wide number of people. Because the interests of particular individuals are not always compatible at the points of most intense reaction (e.g., a particular land use, such as a billboard, which increases the wealth of one person may be to others aesthetically offensive in certain contexts), community officials must sometimes intervene to secure the maximization of all community values. According to our basic social hypothesis, this intervention should occur only when community values are seriously damaged or threatened by specific uses of land. It is for the purpose of achieving the optimum use of its resources and deciding when individual use seriously impedes this achievement, that the community establishes planning boards and courts which shape land use practises and attendant legal doctrines. Precisely under what conditions community values are seriously damaged by individual action is a problem which seldom or never admits of a simple answer, but the answer is more easily reached if it is kept in mind that the ultimate objective of the community is to secure a use of land which promotes the most values for the most people ${ }^{15}$ and facilitates the harmonious functioning of residential, recreational, industrial and business areas.

Now it seems fairly clear that among the basic values of our communities, and of any society aboriginal or civilized, is beauty. Men are continuously engaged in its creation, pursuit, and possession; beauty, like wealth, is an object of strong human desire. ${ }^{16}$ Men may use a beautiful object which they possess or control as a basis

\footnotetext{
14 See Myres S. MeDougal and David Haber, Property, Wealth, Land II3 (1948), and sources cited therein at page 14 .

${ }^{15}$ For development of a particular set of interdependent values, see Lasswell and McDougal, Legal Education and Public Policy: Professional Training in the Public Interest, 52 YALE L. J. 203 (1943).

10 "The fine arts ... are by no means the only sphere in which men show their susceptibility to beauty. In all products of human industry we notice the keenness with which the eye is attracted to the mere appearance of things: great sacrifices of time and labour are made to it in the most vulgar manufactures; nor does man select his dwelling, his clothes, or his companions without reference to their effect on his aesthetic senses. Of late we have even learned that the forms of many animals are due to the survival by sexual selection to the colours and forms most attractive to the eye. There must thercfore be in our nature a very radical and wide-spread tendency to observe beauty, and to value it. No account of the principles of the mind can be at all adequate that passes over so conspicuous a faculty."
} 
for increasing their power or wealth or for effecting a desired distribution of any one or all of the other basic values of the community, and, conversely, men may use power and wealth in an attempt to produce a beautiful object or a use of land which is aesthetically satisfying. It is solely because of man's irrepressible aesthetic demands, for instance, that land with a view has always been more valuable for residential purposes than land without, ${ }^{17}$ even though a house with a view intruding everywhere is said to be terribly hard to live in. Zoning regulations may, and often do, integrate aesthetics with a number of other community objectives, but it needs to be repeatedly emphasized that a healthful, safe and efficient community environment is not enough. ${ }^{18}$ More thought must be given to appearances if communities are to be really desirable places in which to live. ${ }^{19}$ Edmund Burke-no wild-eyed radical-said many years ago, "To make us love our country, our country ought to be lovely." It is still so today.

By assuming, however, that beauty is a matter neither subject to rational criticism nor capable of measurement by precise standards, courts say that although individuals may desire beauty, or, more accurately, what they think is beautiful, community officials qua officials should not be allowed to force their own individual "subjective," "non-measurable," "irrational" aesthetic preferences upon others through use of the police power. This demand for precise criteria by which "beauty" can be measured, which is at the bottom of the judicial refusal to recognize openly aesthetics as a proper police power purpose, seems to be based upon a misunderstanding of the meaning of words. In any event, it needs some looking in to.

This demand assumes that aesthetic inquiries must begin by asking for the meaning of "beauty" and that only if this meaning is discovered can we possibly

The Sense of Beauty, Intro. (1896), in I The Works of George Santayana 5 (1936).

Some writers have suggested that judges are interested in achieving beauty in the syntax of legal doctrine. See Llewellyn, On the Good, the True, the Beautiful, in Law, 9 U. of CH. L. Rev, 224 (1942); Wolfson, Aesthetics in and About the Law, 33 Kx. L. Rev. 33 (1944); Frank, Words and Music: Some Remarks on Statutory Interpretation, 47 CoL. L. REV. I259 (r947), and Courts on TrIaL 292 (1949).

${ }^{12}$ In Miller v. Lawler, 66 N.W.2d 267, 269 (Iowa, x954), the court enjoined defendant from erecting a residence in violation of an alleged oral agreement that defendant would not erect a residence obstructing plaintiff's "'terrific' nine mile view to the south and west across vacant property owned by defendant and to hills and woods beyond." The court held that to obstruct plaintiff's view would irreparably damage his property.

${ }^{18}$ See the essays of Weinberg, Not by Bread Alone: An Evaluation of the Design Element in Large Scale Planning, Gallion, Civic Design and Democracy, and DeMars, Townscape and the Architect: Some Problems of the Urban Scene, in Coleman Woodburr (Ed.), The Future of Cittes and URban ReDEVELOPMENT 52-99 (1953).

30 "The beauty of a fashionable residence neighborhood in a city is for the comfort and happiness of the residents, and it sustains in a general way the value of property in the neighborhood. It is therefore as much a matter of general welfare as is any other condition that fosters comfort or happiness, and consequent values generally of the property in the neighborhood. Why should not the police power avail, as well to suppress or prevent a nuisance committed by offending the sense of sight, as to suppress or prevent a nuisance committed by offending the sense of hearing, or the olfactory nerves? An cyesore in a neighborhood of residences might be as much a public nuisance, and as ruinous to property values in the neighborhood generally, as a disagreeable noise, or odor, or a menace to safety or health." State ex rel. Civello v. New Orleans, 154 La. 271, 97 So. 440, 444 (I923). 
praise or condemn particular objects in our environment. Since beauty has in the past "proved notoriously refractory to definitive methods," that we cannot rationally appraise objects as beautiful. But by asking, "what is beauty?" courts have got themselves into the semantic bog which has long trapped the aestheticians, who too often start their intellectual meanderings in pursuit of that elusive will-o'-the-wisp: the true meaning of beauty. ${ }^{21}$ This same bog lies in the field of jurisprudence, except that judges rarely decide cases by inquiring first, "what is justice?".

Words simply do not have the kind of meaning that judges (and philosophers) are seeking when they ask, "what is beauty?". 2 Words are neither "things" nor "ideas" that can be precisely measured; they have only uses or functions. The word beauty means nothing by itself. To know the meaning of beauty is to know how to use it in an intelligible way to describe phenomena within a given context. One can meaningfully say, for instance, that Corot's "The Forest of Fontainebleau" is a beautiful painting or that the cathedral at Chartres is a beautiful building, but it is fruitless to ask if either is a correct use of beautiful. ${ }^{23}$ Philosophy has many revelations to offer but true meaning of word symbols is not among them.

That words have no single correct meaning points up that whether an object or a relation is beautiful (or "equitable" or "reasonable") hinges upon the perspective of the persons using the word. ${ }^{24}$ This semantic indefiniteness does not, however, force us to the very extreme position of Humpty Dumpty (as some judges assume it does in matters of beauty but not in matters of equity or reasonableness). Of course, if a word cannot be intelligibly used by persons in communication then Humpty Dumpty is right, but there are good psychological and cultural reasons why the usage of words remains fairly stable, ${ }^{25}$ why people can and do meaningfully use the word beautiful. ${ }^{26}$

What this adds up to is this. The cry for precise criteria might well be abandoned because it does not make sense. Beauty cannot be any more precisely defined than

${ }^{20}$ Chas. K. Ogden and I. A. Richards, The Meaning of Meaning 139 (1927).

${ }^{21}$ In general see Katharine E. Gilbert and Helnsut Kunn, A History of Esthetics (1940).

${ }^{22}$ A stimulating examination of the language of aestheticians can be found in Robis G. Collinowood, Prunctples of Art cc. $x$, II, $x_{2}$ (1938). See also Chas. K. Ogden, I. A. Ruchards and J. E. Wood, THE Foundations of AEsthetics (1921); Morris, Esthetics and the Theory of Signs, $8 \mathrm{~J}$. UNIFIed SciENCE I3X (1939); McKeon, The Philosophic Bases of Art and Criticism, 4I Mod. PHiLoLocy 65 (1943).

23 "Dogmatism in matters of taste has the same status as dogmatism in other spheres. It is initially justified by sincerity, being a systematic expression of a man's preference, but it becomes absurd when its basis in a particular disposition is ignored and it pretends to have an absolute or metaphysical scope." The Life of Reason, Reason in Art, c. io, in IV The Works of George Santayana 345 ('Triton ed. 1936).

${ }^{24}$ An excellent exposition of the significance of perspective in aesthetic evaluations is the Gestaltist Hungerland's Perception, Interpretation and Evaluation, 10 J. AEsthetics AND ART Criticism 223 (1952). See also note 33 infra.

${ }^{25}$ See generally P. A. Sorokin, Societr, Culture and Personality: Thetr Structure and Dynamies (1947), and Leslie Spier, A. T. Haliowelt and S. S. Newman (Eds.), Language, Culture and Personality (I94 $x$ ).

${ }^{20}$ See Schrickel, A Psycho-Anthropological Approach to Problems in Aesthetics, to J. AEsTHETICs AND ART CRITICISM 315 (1952). 
wealth, property, malice, or a host of multiordinal words to which courts are accustomed. Planners can give reasons for saying a particular arrangement of objects in the environment is beautiful based upon perspectives common in high degree among the people in a community, but they cannot prove it, and proof which is strictly unattainable should not be demanded. What is needed to decide whether beautiful can be used in an intelligible manner by planners is not a foredoomed search for precise criteria for its correct employment, but rather a clarification of some of the operations indicating how the general public and planners use the word and an evaluation of these operations by reference to community goals. It will have to be admitted that a satisfactory set of operations describing what is beautiful in the varying contexts of land use is not easy to come by. The problem of contriving definitions that meet the operational test of meaning is a complicated, difficult business, for most of the relevant formal indices of beauty (such as symmetry, variety, uniformity, balance, rhythm, simplicity, intricacy, and quantity) will have to be further defined operationally. ${ }^{27}$ It is easy enough for planners to say, "Let beauty represent the ratio of formal indices to function," but it is hard to know what, if anything, they would be talking about.

Furthermore, in specifying and evaluating indices of attractive environments, it is important that community decision-makers-judges and planning officials-realize that they must promote land use which in time will succeed in appealing to people in general. In public planning that environment is beautiful which deeply satisfies the public; practical success is of the greatest significance. ${ }^{28}$ In the long run, what the people like and acclaim as beautiful provides the operational indices of what is beautiful so far as the community is concerned. All popular preferences will never be acceptable to connoisseurs who urge their own competence to prescribe what is truly beautiful, yet it seems inescapable that an individual's judgment of beauty cannot be normative for the community until it is backed with the force of community opinion. History may be of some comfort to the connoisseurs: widely acknowledged great artists and beautiful architectural styles produced popular movements and not cults. ${ }^{29}$ A great age of architecture has not existed without the popular acceptance of a basic norm of design.

\footnotetext{
${ }^{27}$ On operational indices in general see P. W. BridgMan, The Logic of Modern Physics (I927). For the development and application of a detailed set of aesthetic indices see GeORGE D. BirkHoFf, AEsthet7C MEAsURE (I933). Birkhoff takes as his basic formula of beauty the ratio of complexity to order. Complexity and order are refined psychologically and mathematically until specific formulac emerge which are applied to various objects and designs, such as a polygon in vertical position, a simple rectilinear ornament, and a vase. The results, although limited in scope, are closely in accord with long-range critical and popular preferences. An earlier unsuccessful attempt to specify operational indices is Hogarth's classic Anatysis of Beauty (I753).

${ }^{28}$ See John Dewey, ART as EXperience (I934). Compare with Dewey's pragmatics the transcendental approach of Croce, who condemns "as erroneous every theory which annexes the aesthetic activity to the practical." B. Croce, Aesthetic as Science of Expression and General Linguistic 50 (Ainslie transl. 1922).

${ }^{30}$ For divertissement, read John Wilcox's provocative account of how art without purpose and the art for art's sake craze culminating in the dada (hobby-horse) cult of the twenties grew out of a misinterpretation of Kant's Critique of Judgment (1) by Madame de Stäl and others. Wilcox, The Beginnings of L'Art Pour L'Art, II J. Aesthetics AND ART CRITICISM 360 (1953).
} 
Planning attractive communities need not necessarily mean the uniform imposition of the dreary middle-brow tastes of the Philistines. To a large extent artistic preferences are a result of conditioning (not entirely, of course, since even the marvelously adaptive human machine cannot become accustomed to everything). Preferences are formed through what the psychologists call canalization, a type of conditioning which eventually narrows the kind of stimulus that can satisfy a nonspecific demand. The demand will at first be rather general, but through environmental conditioning only one or two stimuli will bring satisfaction. Beauty, as one of the values sought by man, is one of his non-specific demands, and its satisfaction is conditioned by his environment. Objects in the individual's aesthetic continuum with which he identifies himself-to which he has become habituated-will more likely satisfy his demand than objects with which he is unfamiliar. Individuals do not like to impair the identifications of their personality structure, and for that reason resist new designs. ${ }^{31}$ For the same reason, other changes in the environment are resisted. Nevertheless, lively perspicacious leadership in the arts, such as has been provided by the Bauhaus group, the Museum of Modern Art in New York, and other community art centers interested in improving contemporary design, can change-even "improve"-less educated "pedestrian" tastes (to use the jargon of art criticism). The real need is for those who want to influence community artistic preferences to examine, far more closely than has yet been done, the techniques by which contemporary aesthetic opinion is, and could be, manipulated.92

When an individual responds to environmental stimuli by applying the word beautiful to particular objects, an enormous number of variables has influenced the response. These include the specific qualities of the objects perceived (shapes, colors, textures, arrangements, compositions, etc.), the physical and social context of perception, the entire physical and psychological history of the individual, and the values of the percipient and of the community. ${ }^{33}$ All these and infinitely more variables fuse into judgments of beauty. These judgments of beauty are like all other appraisals in that they are made by individuals. They will vary. There is no getting around the inherent limitations on man's power to reason which Kant

\footnotetext{
${ }^{31}$ There is an interesting discussion of this point in KuRT Koffre's Principles op Gestalt PsycholOGY 347 (I935).

${ }^{32}$ For a lively history of the manipulation of American taste, see Russell Lynes, THe TASTE-Makens (1954).

${ }^{33}$ As yet we have little good empirical description of the aesthetic evaluative process and of determining factors in it. Pertinent but limited studies include: Eysenck, The General Factor in Aesthctic Judgements, 3 I Brut. J. Psychologx 94 (1940), and Type Factors in Aesthetic ludgements, id. at 262 (1941); Henry, Art and Cultural Symbolism, A Psychological Stttdy of Greeting Cards, 6 J. Aestuerics AND ARt Cruticism 36 (1947); Gordon, Methodology in the Study of Art Evaltation, yo J. Aestrietics AND ART Criticism 338 (I952). Perhaps the difficulty is that in order to get at the problem at all it is necessary to control the number of variables, resulting in a fatal oversimplification. This difficulty is experienced also by lawyers attempting to describe and weigh the factors in judicial decision.

"Experimental aesthetics," sometimes called "psychometric aesthetics," was a behavioristic approach emphasizing statistical studies of preference. Of it great things were expected, but little has come. See A. R. Chander, Beauty and Human Nature (1934); Farnsworth, Psychology of Aesthetics, in Encyclopedia of PSYchology I2-25 (1946).
} 
demonstrated so many years ago. Still, is it necessary to conclude that because individuals are not perfect judging machines that imperfect but rational evaluations of what land uses are conducive to an attractive community cannot and ought not to be made? It is a pity that aesthetic disagreements cannot be resolved by reference to absolute standards, for we should all feel so much more secure in our judgments. What we need, however, to solve a value problem is not an illusion of an absolute standard but decision-makers whose thinking is sufficiently disciplined and whose technical training and knowledge of human beings are sufficiently extensive to qualify them to pass judgment on the particular problem and to develop rational techniques for implementing our generalized, flexible, relativistic community values.

The Implementation of Values

Consideration of some specific land uses which have been widely thought to be aesthetically objectionable will show, perhaps, some types of aesthetic regulation rational community planning requires and how contemporary doctrine impedes the efficient implementation of community values. It will become apparent that the question of methodology of value implementation really needs far more extensive consideration than it has ever received in the past and far more than can be given it here. The following is intended to be more suggestive than comprehensive.

\section{A. Control of Building Design}

Many of the restrictions upon land use have, at one time or another, been said to be for aesthetic objectives. Indeed, many years ago it was thought by some that the main purpose of a city plan was to create a City Beautiful. Even today claims that building restrictions such as minimum lot size and minimum floor plan provisions have mainly an aesthetic purpose are not unusual, but here it would seem almost impossible to separate considerations of beauty from considerations of health, safety, and other factors. ${ }^{34}$ Because these other objectives are so obviously involved courts have usually sustained reasonable minimum size provisions and have not recently struck down any provision of this type on the ground it was solely for an aesthetic purpose. If minimum size restrictions are without the police power, it is for some reason other than that their objective is aesthetic and thus a discussion of minimum size provisions is not directly pertinent here.

There are, none the less, certain community restrictions on land use which ruins the amenity of the neighborhood simply because it involves deviation from the neighborhood scheme and is considered unattractive. People expect and demand protection against deviations which they consider too ugly, and in new subdivisions protect themselves with private restrictive covenants, ${ }^{35}$ but in the older areas reliance

${ }^{34}$ See discussion of the Wayne Township minimum size provisions and community objectives by Haar, Zoning for Minimum Standards: The Wayne Township Case, 66 Harv. L. Rev. Io5I (r953), and by Nolan and Horack, How Small a House?-Zoning for Minimutm Space Requirements, 67 Harv. L. REv. 967 (1954), and reply by Haar, $i d$. at 986 .

${ }^{36}$ Harold L. Reeve, The Influence of the Metropolis on the Concepts, Rules and Institutions Relating to Property Ir4-124 (I954). 
necessarily is to a large extent on the intervention of community officials. Examples of these aesthetically motivated restrictions are requirements of two-story houses, ${ }^{30}$ of conformity to building line, ${ }^{37}$ and of larger front yards in the quieter, more exclusive residential areas with the least traffic. ${ }^{38}$

Some cities with a distinctive architectural tradition have attempted to control the architectural design of buildings by establishing a public body to pass upon the design of private buildings. New Orleans, ${ }^{30}$ Williamsburg, ${ }^{40}$ Santa Barbara, ${ }^{41}$ and West Palm Beach are examples. Apparently the only reported court test of an ordinance of this type involved the West Palm Beach one, and it was held void as not related to "health, welfare, safety or morals." 2 It is clear that restrictions on building design have aesthetic objectives in mind more than anything else; it also seems to me that in certain contexts such restrictions may be reasonable means of policy implementation. ${ }^{43}$

${ }^{36}$ Baker v. Somerville, ${ }_{13} 8$ Neb. $466,471,293$ N.W. 326,328 (1940) (ordinance requiring twostories held invalid; "it resulted alone from aesthetic standards of the city lawmakers"); Brookdale Homes v. Johnson, 123 N.J.L. 602, ro A.2d 477 (1940) (ordinance requiring roof ridge to be at least 26 feet above foundation held invalid). Cf. 122 Main St. Corp. v. Brockton, 323 Mass. 646, 84 N.E.2d I3 (1949) (ordinance fixing minimum height for buildings in business area held invalid).

${ }^{37}$ Gorieb v. Fox, 274 U.S. 603 (1927) (ordinance sustained as reasonably related to public safety, health, morals or general welfare). Cf. St. Louis Poster Advertising Co. v. St. Louis, 249 U.S. 269, 274 (1919) (ordinance requiring billboard conformity to building line sustained, Holmes, J., saying, "Possibly one or two details, especially the requirement of conformity to the building line, have acsthetic considerations in view more obviously than anything else"). See cases collected in EugEnE MicQuiLLiN, The Law of Municipal Corporations \$25.138 (I950).

${ }^{38}$ Sundeen v. Rogers, 83 N. H. 253 , $x_{4}$ I Atl. 142 (1928) (ordinance requiring garages, pergolas, and other auxiliary buildings to be built behind main house sustained on ground it promoted public health and safety). CF. In re Parker, 214 N.C. 51 , 197 S.E. 706 (1938) (ordinance prescribing maximum height of 6 feet for walls or fence in rear of residence sustained in its application to plaintiff, although the city's superintendent of parks, a landscape architect, and plaintiff's neighbors all testificd that because of the unusual topography of plaintiff's lot his wall was in no way aesthetically objectionable). See cases cited in McQuiliIN, op. cit. supra note $37, \$ 25.140$.

${ }^{39}$ The Vieux Carré Commission, by virtue of the Louisiana Constitution, Art. XIV, $\$ 22 A$ (adopted I936), has control "over the architecture of private and semi-public buildings erected on or abutting the public streets of said Vieux Carré section. . . [Without Commission approval no building can be erected or altered in] appearance, color, texture of materials and architectural design of the cxterior. . ." See New Orleans v. Pergament, r98 La. 852, 5 So.2d I29, 130 (I94I); New Orleans v. Levy, 223 La. $x_{4}, 64$ So.2d 798 (1953).

${ }^{10}$ Williamsburg, Virginia, Ordinance No. 2I, $\$ 23-45$ (adopted I95I), provides that any building erected "shall have such design and character as not to detract from the value and general harmony of design of buildings already existing in the surrounding area in which the building is located or is to be located."

"Santa Barbara, California, Ordinance No. 2228, §1 (adopted 1949).

2 City of West Palm Beach v. State ex rel. Duffey, 158 Fla. 863, 30 So.2d 49x, 492 (1947). The ordinance provided that "the completed appearance of every new building or structure must substantially equal that of the adjacent buildings or structures in said subdivision in appearance, square foot arca and height."

$\$ 3$ Caveat: "Because this is a new development, home builders are likely to feel that a provision for architectural supervision is an unreasonable imposition, and in cases where the planning agency has no expert architectural aid, this criticism will frequently be justificd. . . .

"What success the California counties have had with this provision has been due largely to the discretion with which planning commissions have used the power granted. In every instance architects or other experts have guided the commission, and in virtually every case applicants for building permits whose plans did not meet the approval of the commission have been persuaded that the changes suggested were desirable. Without such careful and sparing use of the provision for architectural super- 
Our communities need to achieve an environment that is emotionally satisfactory, that effects a reduction in purposeless nervous and physical tensions of the inhabitants. When the inner life of an individual is out of balance, anxiety occurs, expressing itself in a number of socially destructive ways. ${ }^{44}$ Architecture, indeed every object in the individual's aesthetic continuum, has a direct effect upon the equilibrium of his personality and upon the happiness and richness of his life. ${ }^{45}$ Community officials need to become more aware of the significance design holds for each individual and thus for society.

Zoning restrictions which implement a policy of neighborhood amenity should be voided, if at all, not because they are for aesthetic objectives but only because the restrictions are unreasonable devices of implementing community policy. Whether, I repeat, an ordinance of this type should be declared invalid should depend upon whether in the particular institutional context the restriction was an arbitrary and irrational method of achieving an attractive, efficiently functioning, prosperous community-and not upon whether the objectives were primarily aesthetic. It is obvious that the task of determining whether a restriction is arbitrary and unreasonable is not an easy one, but it certainly is not made easier by theory which turns a deaf ear to aesthetic effects. Before planners or courts can make a fully rational decision, they need to hear arguments as to the effect of a proposed decision on all community values. They need to know, inter alia, how the zoning ordinance will affect the distribution of community wealth, especially neighboring

vision, the requirement would likely prove exceedingly dangerous." Lesgue of Minnesota MUNicipaIIties, Zoning, A Guide for Minnesora Cities and Villages i0-it (I952).

"For examples, see the pamphlet of the Park Association of the City of New York, VANDALISM IN City Parks (1952).

"Strictly speaking, although confirmed on occasion by individuals who have subjected their personality structure to depth study, this statement is common sense conjecture not based upon any empirical evidence of the effect of the physical environment on personality. After a fairly comprehensive search, I am unable to find any good study of this problem and my colleagues in sociology and psychology tell me none has been made. In his recent book, Survival Through Design 334 (1954), Richard Neutra suggests what is needed. He calls for a five-fold investigation:

"r. To ascertain the force of influences of environment affecting the organism generally, not through the senses. Special consideration will be given to stimulations that are man-made or modifiable and therefore within the province of the art of design.

2. To clarify data on specific sensory responses, to show how the many senses work, singly and in 'stercognostic' combination.

3. To study the relation of stch sensory stimulation to an inner somatic equilibritum, which is fundamental to our immediate well-being and our ultimate survival.

4. To study with care conditioned and associated responses elicited in our brain by simple design elements.

5. To investigate with ever-greater refinement and dependability the interrelations of all responses, their superpositions, their colligations, configurations, and mutual interferences."

Among the books which provide some insight into the problem are: Thomas A. RYan And P. C. Smith, Principles of Industrial Psychology c. 12 (1954); Charles M. Harsh and H. G. Schrickel, Personality: Development and Assessment c. I (I950); Douglas G. Haring (Ed.), Personal Character and Cultural Milieu (I949); L. B. Murphy and T. M. Newcomb, Experimental Social Psichology (I937); Morgan, Human Engineering, in Wayne Dennis (Ed.), Current Trends IN Psychology (r947); James S. Plant, Personality and the Cultural Pattern Pt. II (1937); Edgar Sydenstricker, Health and Environment (i933); Charles W. Valentine, AN Introduction to the Experimental Psychology of Beauty (1913). 
property values on which taxes and the financial security of the city depend, ${ }^{40}$ how the ordinance will affect the well-being of the community as a whole, including the effect upon physical and mental health and safety of the residents, and how the ordinance will increase the attractiveness of the community. ${ }^{47}$ They need to know about matters which contemporary doctrine may exclude from evidence. ${ }^{48}$

Undoubtedly courts do take aesthetics into consideration by smuggling aesthetic effects into the judicial ken by a kind of "judicial notice" and evaluating them by a mysterious and very inarticulate intuition. But too often this results in a court being fooled by its own Gestalt; too often it results in a decision as to the reasonableness or unreasonableness of an ordinance without careful consideration of extrinsic evidence of its aesthetic effect. Are not the defects of a legal system in which words do not match action, in which the gap between myth and decision is great, many and patent?

\section{B. Billboards, Gravel Pits, and Junk Yards}

American prosperity owes much to advertising. It has played an important role in creating the widespread demand for more creature comforts resulting in more jobs, more volume for manufacturers and retailers, and, as Russell Davenport and the editors of Fortune put it, "The Permanent Revolution"40 in the economic and social organization of American communities. We should be appropriately cautious about curtailing an activity which has been instrumental in increasing our wealth and effecting a wider sharing of it, but where it conflicts with another community value one has to give way. In the beginning, beauty was expendable, but the early billboards were in such profusion and in such vulgar taste ${ }^{50}$ that courts finally had

\footnotetext{
${ }^{46}$ See Sayre, Aesthetics and Property Values: Does Zoning Promote the Public Welfare?, 35 A.B.A.J. 47 r (1949).

${ }^{47}$ Lewis Mumford, The Culture of Cities (1938), Catherine Bauer, Modern Housing (1934), and Coleman Woodbury (Ed.), The Future of Cittes and Urban Redevelopment (1953) contain a wealth of information regarding the effect of community design upon the social, health and economic structure of communities here and abroad.

${ }^{\star 8}$ E.g., in Neef v. Springfield, 380 Ill. 275,43 N.E.2d 947 (1942), the issue was the validity of a Springfield ordinance prohibiting gasoline filling stations on Monument Avenue lcading to Lincoln's Tomb. The city officials "were permitted to testify . . that their chief concern was the prescrvation of the beauty of the street." This testimony was dismissed by the Supreme Court of Illinois as "wholly immaterial and incompetent." "The question here," said the court (at page 950), "is whether or not, disregarding the evidence relating to the beauty of the neighborhood and the streets and other aesthetic purposes, the ordinance should be sustained on the grounds of public health, safety, morals or general welfare." The ordinance was ultimately sustained.

10 Russell W. Davenport et al., U. S. A. The Permanent Revolution (ig5i).

${ }^{\circ}$ Many of the carly posters could fairly be characterized as suggestive or lewd, and after much public pother these were subjected to the scrutiny of a censorship committee of the organized billposters. Like all censors they sometimes outdid themselves. In England, for instance, the pictorial representation by Bovril of an entire bull was condemned as likely to corrupt morals, and to this day only the bull's head is used by Bovril. Other posters likely "to be embellished by the lewd artistry of the street loafer" were ordered hung high. Cyril Shezdon, A History of Poster Advertising 70 (1937). Sec also Civic League of St. Louts, Bilzboard Advertising in St. Louis (19ro). The industry clean-up did not, however, satisfy civic leaders and nature lovers who continued to produce a host of amusingly vituperative pamphlets. Almost any city library will have a collection of these.

Public distaste for billboards became so strong that the term is now verboten in the advertising world. Modern husksters, scorning Shakespeare's dictum about a rose, insist that billboard has been
} 
to allow their curtailment, even though the protection of property interests was at that time constitutionally in a preferred position. Today, most of the existing billboard blight is there by sufferance or inertia of community officials, since it is no longer doubted that billboards in a wide variety of institutional contexts may be regulated. By statute $I 7$ states provide for comprehensive regulation, ${ }^{51}$ and $I 6$ states specifically provide for regulation by municipalities. ${ }^{52}$ Practically every large city regulates outdoor advertising by ordinance or zoning law..$^{53}$ All of the recent cases indicate court approval of community intervention against billboards, ${ }^{54}$ a few lower courts even saying as well as holding that the police power may be used to secure aesthetic objectives. ${ }^{55}$ This victory over ugliness is undoubtedly due largely to the

superseded by poster panel and painted display bulletin. One "spokesman" for the advertising trade in a 310 page textbook on outdoor advertising (Hugh E. AGNEw, Outdoor ADvertising (I938)) mentioned billboard only once, to say the term was obsolete, and the Director of the Westchester County (N.Y.) Department of Planning, in an appearance on a Philadelphia television station, was carefully told not to use the word billboard as it might offend some of the clients of the station. In spite of the billposters' efforts, the old-fashioned word remains firmly fixed in the vernacular.

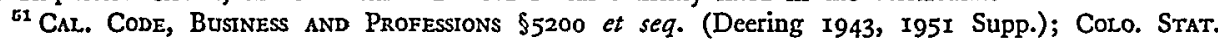
ANN. c. $48, \$ 403$ (I) et seq. (1953 Supp.); DeI. CODE ANN. \$ryor et seq. (1953); D. C. CODE \$1-23I (I95I); Fla. Stat. AnN. c. 479 (I952); KY. Rev. Stat. \$147.080 (I953); ME. Rev. Stat. c. 20, \$III et seq. (1944); MD. ANN. CODE art. 56, \$208 et seq. (195I); Mass. Gen. Laws c. 93, \$\$29-33 (Michie, 195I); Nev. Conp. Laws \$260 et seq. (Hillyer, I929); N. J. Stat. Ann. \$54:40-1 et seq. (I937); N. M. Stat. Ann. $\$ 58-708$ et seq. (I94X); N. C. Gen. Stat. \$105-86 (I949); Tenn. Code Ann. \$1248.14, \$5753 et seq. (Williams, 194I); VT. STat. \$7676 et seq. (I947); VA. Code \$33-298 et seq. (I950); W. VA. CODE ANN. \$I72I(49) et seq. (1949).

${ }_{52}$ Cal. Gov't Code $\$ 38774$ (Deering, I943, I95I Supp.); Conn. Gen. Stat. Rev. $\$ 837$ et seq. (1949); Ill. ANn. Stat. c. 24, \$23-22 (Smith-Hurd, I942); Iowa CODE ANn. \$368.6 (I946); KAN. Gen. Stat. Ann. \$§I3-406, I4-431 (1949); Mich. Stat. Ann. \$5.2082 (1949); Minn. Stat. Ann. $\$ \$ 4 \times 1.40(8), 462.12,463 . \pi_{3}(4)$ (1945); Mo. ANN. STAT. $\$ \$ 74.145(9)$, 75.IIo(42) (I949); N. Y. VILLAGE Law \$89(47) (McKinney, I951); OHo Rev. Code \$715.27 (Page, I953); R. I. Gen. Laws c. 375 (1938); Tex. Civ. Stat. art. II75 (24) (Vernon, 1953); UTah Code ANn. \$ro-8-39 (r953); VT. Stat. $\$ 3847$ et seq. (1947); W. VA. Code ANN. \$59I(83) (1949); WIs. STAT. \$59.07(16) (I95I).

${ }^{3}$ See Chardes S. Rhyne, Municipal Regulation of Signs, Billboards, Marquees, Canopies, Awnings and Street Clocks, Rep, No. 137, National Institute of Municipal Law Officers (I952). Gannon, The Law of Zoning Ordinances in Pennsylvania, I6 U. PITT. L. Rev. 168 (I955).

"Murphy v. Westport, supra note 8: General Outdoor Advertising Co. v. Dep't of Public Works, stipra note II; General Outdoor Advertising Co. v. Indianapolis, 202 Ind. 85, I72 N.E. 309 (1930); Perlmutter v. Greene, 259 N.Y. 327, I 82 N.E. 5 (I932). Other cases are cited in MicQuiLliN, op. cit. supra note $37, \$ \$ 24.380-8$. But cf. Mid-State Advertising Corp. v. Bond, 274 N.Y. 82, 8 N.E.2d 286 (1937).

${ }^{65}$ Commonwealth v. Trimmer, 53 Dauphin Co. Rep. 9I, I05 (Pa. I942): "We definitely hold . . . that aesthetic considerations alone, in this day, are sufficient upon which to base an exercise of the police power." Preferred Tires v. Hempstead, I73 Misc. Ior7, I9 N.Y.S.2d 374, 376-377 (1940): "Plaintiff lays stress upon the claim that aesthetic considerations are the basis for the enactment of the ordinance in question and he quotes extensively from decisions in which the courts of this state have vecred away from sustaining similar enactments for aesthetic reasons only. ... This court ... would not hesitate to sustain the legislation upon that ground alone. . . Beauty tends to the happiness, contentment, comfort, prosperity and general welfare of our citizens. . . The courts should not be so bound down with ancient precedent that they should close their eyes to every change." People v. Wolf, N.Y.L.J. Dec. 23 , I925, affirmed, 220 N.Y.S. 656 (1926), reversing 127 Misc. 382 , 216 N.Y.S. 74 I (I926), appeal dismissed, 247 N.Y. I89, I59 N.E. 906 (I928): "I am of the opinion that an ordinance prohibiting or regulating outdoor advertisements for the purpose of maintaining a certain aesthetic standard is valid if reasonable under the particular circumstances of the community in which it is to operate." The Massachusetts Supreme Judicial Court seems to be the only state court of last resort which has come out and said plainly that proseription of some billboards "rested solely on the grounds of taste and fitness" and which has held that on those grounds they may be regulated. General Outdoor Advertising Co. v. Dep't of Public Works, stpra note II, 289 Mass. at I99-20I, I93 N.E. at 822-823. 
growth of other more effective advertising mediums-newspapers, magazines, radio, and television-with a resultant lessening of demand by business interests for billboard space and community protection.

Although much has in fact been accomplished, there is still a considerable amount of confusion as to what community officials can and cannot do. Most courts have not yet openly recognized that a rational decision as to which signs should be protected and which prohibited in the interest of optimizing community values depends upon a number of variables, chief of which is the environmental context.50 One of the principal reasons for the present confusion about what signs community officials can and cannot regulate is the failure of contemporary doctrine to make certain minimal contextual distinctions. The doctrine prohibiting zoning for aesthetic objectives applies both to advertising in areas devoted to residential and recreational functions and to advertising in manufacturing and retailing areas as if the context were not important in determining community policy and how to implement it. The doctrine fails to prescribe in what contexts advertising may be prohibited because not amenable to the environment.

Along with advertising signs are some other uses which in certain environments are entirely out of keeping. Among these are gravel pits and junk yards, which have been restricted by many communities. Ordinances prohibiting removal of topsoil and excavation of sand and gravel have been dealt with by several courts in the last 20 years. In New York, the ordinance of the town of Harrison, a wealthy commuters' community in Westchester County, prohibiting removal of top soil and excavation of sand, stone, and gravel was held to be an invalid exercise of the police power because solely for an aesthetic purpose, ${ }^{57}$ but it is believed that on the basis of later cases $^{58}$ involving somewhat similar ordinances the holding in the Town of Harrison case is of doubtful authority. In Massachusetts, the Supreme Judicial Court, frankly recognizing the aesthetic factor, upheld a Burlington ordinance prohibiting stripping of topsoil on the ground that unsightly land depressed the taxable value of neighboring property. ${ }^{59}$ It seems probable that other courts will

${ }^{56}$ In England outdoor advertisements may be prohibited only "in the interests of amenity and public safety." See the Town and Country Planning (Control of Advertisements) Regulations, 1948, Part II(4), S. I. 1948 , No. 1613 .

${ }_{57}$ Town of Harrison v. Sunny Ridge Builders, I70 Misc. I6r, 8 N.Y.S.2d 632 (1938). Cf. Lizza \& Sons v. Town of Hempstead, I75 Misc. 383,23 N.Y.S.2d 811 (1940).

${ }^{68}$ Lizza \& Sons v. Town of Hempstead, 69 N.Y.S.2d 296 (1947), affirmed, 272 App. Div. 921, 7x N.Y.S.2d I4 (2d Dep't I947); Krantz v. Town of Amherst, x92 Misc. 812, 80 N.Y.S.2d 812 (1948); Burroughs Landscape Const. Co. v. Town of Oyster Bay, 186 Misc. 930, 6r N.X.S.2d I23 (1946); People v. Gerus, 69 N.Y.S.2d 283 (1942); People v. Calvar Corp., 286 N.Y. 419,36 N.E.2d 644 (194I).

${ }^{\circ}$ Burlington v. Dunn, 318 Mass. 216, 22x, 6I N.E.2d 243, 246, cert. denied, 326 U.S. 739 (x945): “. . The stripping of the top soil from a tract of land ... leaves a desert area in which for a long period of time little or nothing will grow except weeds and brush. It permancntly destroys the soil for agricultural use and commonly leaves the land almost valueless for any purpose. The effect of such an unsightly waste in a residential community can hardly be otherwise than permanently to depress values of other lands in the neighborhood and to render them less desirable for homes. . . . It is natural that a town of the character and situation of Burlington should endeavor to protect itself against such consequences." Accord: Billerica v. Quinn, 320 Mass. 687, 7 I N.E.2d 235 (1947). Whenever courts talk about declining property values, it is, according to Norman Williams, Jr., Director of the 
follow here the view of the Massachusetts court, which has the distinction of having written some of the most vigorous, realistic and illuminating opinions on the question of zoning for aesthetic objectives. ${ }^{61}$ As for junk yards, there is little doubt that they may be kept out of residential areas. But may they be prohibited from locating in plain view of a well travelled highway? Two courts, reciting the traditional anti-aesthetic doctrine, have recently said not. ${ }^{62}$ The problem of ugly junk yards in view of highways is similar to the problem of billboards on highways which still occasionally perplexes community officials trying to achieve attractive landscape design within the confines of contemporary doctrine. ${ }^{63}$ There may be excellent reasons for promoting the aesthetic well-being of travellers on the highway; ${ }^{64}$ the British Parliament has found junk yards on major public highways so objectionable that it has required that they be attractively fenced in. On the other hand, there may be no reasons. The point is, courts and planners need to hear arguments which they are not now hearing.

There are of course variables other than area function which are relevant in determining what is the most rational use of land. In areas in which outdoor advertising would seem perfectly amenable to the milieu, community officials may find other good reasons for intervention. Take the recent cases involving prohibition of overhanging signs in fashionable shopping areas. ${ }^{65}$ This prohibition is far more difficult to justify in terms of area function than the prohibition of advertising signs in residential areas, but it has caused courts much less trouble. The courts have not resisted this phenomenon most probably because the community officials have

Planning Division of the New York City Department of City Planning, "a safe bet that either an aesthetic or psychological nuisance is involved." Deficiencies of Zoning and Legal Decisions, Planning I64 (1950).

${ }^{01}$ The most famous, of course, is General Outdoor Advertising Co. v. Dep't of Public Works, supra note Ir. This decision is discussed at length by Gardner, supra note $x$. The doctrine of that case was extended in Lexington v. Govenar, 295 Mass. I, 36, 3 N.E.2d 19, 22 (1936), to uphold prohibition of professional signs in residential districts: "Doubtless aesthetic considerations play a large part in determining that advertising signs should not be permitted in such an area-these would seem sufficient to exclude such a use." But cf. Barney \& Casey Co. v. Milton, 324 Mass. 440, 87 N.E.2d 9 (1949).

${ }^{\circ 2}$ Vermont Salvage Corp. v. St. Johnsbury, II3 Vt. 34I, 34 A.2d I88 (I943); Pfister v. Municipal Council of Clifton, r33 N.J.L. r48, 43 A. 2 d 275 (1945). But cf. St. Louis v. Friedman, 358 Mo. $68 \mathrm{I}, 216$ S.W.2d 475 (1948).

${ }^{03}$ In Ellis v. Ohio Turnpike Commission, r62 Ohio St. 86, r20 N.E.2d 7r9 (1954), a Commission resolution prohibiting the owner of land taken for the turnpike to place upon his remaining lands "any billboard, sign, notice, poster, or other advertising device which would be visible from the travelway" was invalidated as ultra vires and, in addition, was found too vague and ambiguous for enforcement. By dictum the court said (at page 723) that with specific authority from the legislature the Commission might prohibit billboards "in the interests of safety and to insure an uncluttered view of the landscape." Compare Kelbro, Inc. v. Myrick, I $1_{3}$ Vt. 64, 30 A.2d 527 (I943), which held that the abutting landowner had no right ("easement appurtenant") to have his advertising signs seen from the highway unless they referred to business conducted on the premises. Also compare Perlmutter v. Greene, supra note 54, holding state highway superintendent might obliterate view of billboard by crecting blind in front of it on highway right-of-way. See Wilson, Billboards and the Right to Be Seen from the Highway, 30 GEo. L. J. 723 (1942).

ou See the Maryland Legislative Council Research Reports on Rioadside Controi No. 5 (i940) and No. 20 (1942); Olds, Billboards Along the Highways, 26 Mrch. S. B. J. 15 (1947).

or See note ${ }^{3}$ supra. 
acted here with merchant support, unlike the billboard cases, and a demand by hardheaded businessmen for beauty is very hard to resist. ${ }^{66}$ With the burgeoning of convenient and attractive suburban shopping centers and the discovery that customerpleasing locales draw customers, downtown businessmen have become more than ever alive to the need of making their stores attractive in appearance. The promotion of beauty has become good business. Business support of art has not even been entirely short-term self-seeking. Since the thirties, business has spent millions pioneering the field of industrial designing and millions more in the promotion of fine arts unrelated to industrial uses. ${ }^{67}$ In the name of public relations, good design has become a major factor in the construction of the formerly drab and nondescript office building. For instance, Lever House (home of Swan, Lux, Rinso, Surf, Breeze, and Spry) was built on New York's Park Avenue with no first floor shops, usually a source of considerable calculable income, in order to benefit-incalculably-from public goodwill engendered by gazing upon a building which critics almost unanimously have praised with superlatives. No city today is without some building undergoing a face-lifting-not because the old façade needs repair but because it is ugly. Although this marriage of business and beauty is one of convenience and may be severed at any time, if the coupling brings about open recognition of the value of an attractive community, it will help secure more rational land planning and thereby the achievement of more attractive communities.

\section{ConCLusion}

If we want our children to grow up in pleasant purlieus, we must give up something of the freedom of the individual to use his land as he chooses. This is inherent in the concept of land planning by community officials. Nevertheless, I do not wish to leave the impression that I think it either necessary or desirable that community officials be arbiters in all questions of aesthetic preference which crop up from the use of land. According to our basic social hypothesis, they should interfere only when individual use seriously hampers the achievement of community goals. If community officials instigate an artistic inquisition, it is certainly the court's duty to oppose it, but the cases do not suggest that community officials have acted rashly in attempting to improve appearances. In fact, they seem to have lagged far behind public execration of eyesores, ${ }^{68}$ and when they have acted ex-

${ }^{B 0}$ On this latter point it is interesting to compare the dictum in Miami Beach v. Ocean \& Inland Co., I 47 Fla. 480,3 So.2d 364,367 (I94I) ("It is difficult to see how the success of Miami Beach could continue if its aesthetic appeal were ignored because the beauty of the community is a distinct lure to the winter traveler") with the holding of the Florida court invalidating the West Palm Bcach architcctural control ordinance, stupra note 42.

o7 "The Museum of Modern Art, for example, has fifty 'Corporate Members' who pay up to $\$ 1000$ a year. The list includes such firms as Monsanto Chemical, I.B.M., Yale \& Towne, Lord \& Taylor, and the Columbia Broadcasting System." Russell Lynes, The Taste-Makers 299 (I954).

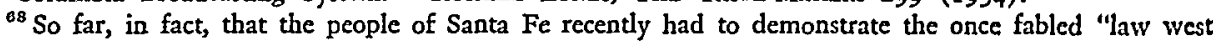
of the Pecos." According to the Santa Fe New Mexican of April 4, 1949, "The wind or the snow or something smashed down three large billboards and six smaller ones along the road between Pojoaque and the Otawi bridge last night. The big commercial boards were leveled as though cut by saws. Two of the large signs had advertised whisky brands. The felling of the signs followed similar acci- 
tensive damage to community values has usually already been done. It is a pity, but it is not entirely their fault. Without frank judicial acceptance of beauty as a proper community objective attainable through use of the police power, the maximization of all community values is impossible and ordinances attempting to prevent eyesores generally become makeshift and piecemeal devices.

Zoning doctrine is still in its formative period; the complexion of our landscape for a long time in the future will be determined by our present attitudes toward zoning for aesthetic objectives. ${ }^{69}$ It seems to me that something more is needed than a case-by-case exception to the general rule, something approaching more closely to a systematic theory of planning which will cover the presently widely accepted doctrines as well as develop new ones to replace those which are now causing us trouble. A tabulation of differentiated factual situations in which restrictions were judicially approved gives community officials a more penetrating insight into the non-meaningfulness of our contemporary authoritative doctrine about aesthetics, but if we would have anything approaching a scientific method in law, we need a body of meaningful postulates and propositions, the efficacy of which is verifiable by case results and evaluated by community goals. Those courts which postulate that the police power may not be exercised for aesthetic objectives obscure the goals toward which community policy is directed ${ }^{70}$ and hinder a determination of what types of aesthetic regulation are required by rational community planning. An effective doctrine for aesthetic zoning may, probably should, provide for careful judicial supervision of the exercise of planning powers in this field. But whatever norm is adopted ought to be based upon an adequate recognition and description of the real factors which motivate decisions of planning boards and courts.

dents to other boards set up in the locality where residents have taken a particular pride in the natural scenery." The newspaper editorially deprecated this "lawlessness" but pointed out that "until there is legal control of billboards, property owners and nature lovers will continue to handle the situation with any means at hand."

${ }^{\circ}$ In connection with the effect of doctrine upon the pattern of land use, Judge Jerome Frank suggests that the growth of skyscrapers in this country has been materially aided by the doctrine that easements of light and air may not be acquired by prescription (see Parker \& Edgarton v. Foote, I9 Wend. (N.Y.) 309 (1838); Depner v. U. S. Nat. Bank, 202 Wis. 405, 232 N.W. 85I (x930); Lynch v. Hill, 24 Del. Ch. 86, 6 A.2d 6r4 (1939); Maioriello v. Arlotta, 364 Pa. 557, 73 A.2d 374 (1950); Kulbitsky v. Zimmoch, 77 A.2d 14 (Md. 1950). In England the doctrine is to the contrary. Lemaitre v. Davis, Ig Ch. D. $28 \mathrm{I}$ (I88x). In a recent letter (dated Dec. 8, I954) to the author, Judge Frank states: "Had the English rule been accepted here, no one could have built a skyscraper in a large city without buying up the easements of adjacent owners. Perhaps such purchases would have been made. But the existence of such easements, and the expense involved in purchasing them, might well have created an inertia sufficient to impede, at least, the development of those beautiful monstrosities."

${ }^{70}$ Note the frank recognition of aesthetics by Mr. Justice Douglas in Berman v. Parker, 348 U.S. 26,33 (1954): "The concept of the public welfare is broad and inclusive. ... The values it represents are spiritual as well as physical, aesthetic as well as monetary. It is within the power of the legislature to determine that the community should be beautiful as well as healthy, spacious as well as clean, well-balanced as well as carefully patrolled. In the present case, the Congress and its authorized agencies have made determinations that take into account a wide variety of values. It is not for us to reappraise them. If those who govern the District of Columbia decide that the Nation's Capital should be beautiful as well as sanitary, there is nothing in the Fifth Amendment that stands in the way." Although eminent domain was involved here, the implications of the language seem very wide. The case may well provide the needed watershed in the field of aesthetic zoning. 